\title{
Satisfaction with treatment of atopic dermatitis in children
}

\author{
Satysfakcja z leczenia atopowego zapalenia skóry u dzieci
}

\author{
Małgorzata Maciejewska-Franczak', Paweł Majak², Jadwiga Kaczmarek³ Adam Antczak $^{4}$ \\ IMAC-MED Outpatient Clinic of Allergology, Pabianice, Poland \\ 2Department of Internal Diseases, Asthma and Allergy, Medical University of Lodz, Lodz, Poland \\ ${ }^{3}$ Barlicki University Hospital Outpatient Clinic of Allergology, Lodz, Poland \\ ${ }^{4}$ Department of General and Oncological Pulmonology, Medical University of Lodz, Lodz, Poland
}

Przegl Dermatol 2016, 103, 109-118

DOI: 10.5 | |4/dr.2016.59132

\section{KEY WORDS:}

atopic dermatitis, satisfaction with treatment.

SŁOWA KLUCZOWE: atopowe zapalenie skóry, satysfakcja z leczenia.

\section{ADDRESS FOR \\ CORRESPONDENCE:}

Adam Antczak MD, PhD

Department of General and

Oncological Pulmonology

Medical University of Lodz

22 Kopcińskiego St

90-153 Lodz

E-mail:

adam.antczak@umed.lodz.pl

\begin{abstract}
Introduction. Atopic dermatitis is a frequent chronic skin disease in children. The major clinical manifestations include itching and dryness of the skin. The pathomechanism of skin changes results from an interaction of genetic and environmental factors as well as impairments of skin barrier function and immune response. Despite chronic treatment the disease is characterized by exacerbation and remission periods and lowers the quality of life of patients and their families.
\end{abstract}

Objective. To evaluate treatment satisfaction in children with atopic dermatitis, identify components of medical care which contribute to treatment satisfaction, and evaluate the relationship between satisfaction and adherence to a doctor's recommendations.

Material and methods. One hundred and nineteen children (6 months to 12 years old, mean age 4.9 years) with atopic dermatitis were enrolled in the study. The doctor performed physical examinations and history taking and filled in questionnaires evaluating the course and exacerbation of the disease, the type of administered therapy and diagnostics. The patients' parents completed two questionnaires: a questionnaire assessing satisfaction with the therapy (the type of recommended therapy, adherence to recommendations, contact with the doctor, obtained information, degree of psychological support, role of parents in taking decisions regarding the therapy) and a quality of life questionnaire.

Results. The authors observed that $56 \%$ of parents were dissatisfied with the administered treatment, and $40 \%$ failed to adhere to at least one therapeutic recommendation. Parents of children with mild atopic dermatitis significantly more often stop using emollients. It was also observed that lack of treatment satisfaction in children with severe atopic dermatitis whose parents are insufficiently educated contributes to decreased adherence. The authors identified independent factors of lack of treatment satisfaction: failure to obtain enough psychological support $(\mathrm{OR}=20.00)$, failure to obtain reliable information on the disease $(\mathrm{OR}=5.91)$, failure to actively get engaged in the treatment procedure $(\mathrm{OR}=5.31)$, dissatisfaction with the contact with the doctor $(\mathrm{OR}=4.9)$, dissatisfaction with the diagnostics $(\mathrm{OR}=4.93)$ and severe course of the disease $(\mathrm{OR}=2.82)$.

Conclusions. Elimination of risk factors of dissatisfaction with the treatment might potentially improve the adherence to chronic treatment in atopic dermatitis. 


\section{STRESZCZENIE}

Wprowadzenie. Atopowe zapalenie skóry (AZS) jest częstą przewlekłą chorobą skóry u dzieci. Głównymi objawami klinicznymi są suchość skóry i świąd. Patomechanizm zmian skórnych jest wynikiem interakcji między czynnikami genetycznymi, środowiskowymi, zaburzeniami funkcjonowania bariery skórnej a odpowiedzią immunologiczną. Pomimo stosowania przewlekłego leczenia choroba przebiega z okresami zaostrzeń i remisji, obniża jakość życia pacjentów i ich rodzin.

Cel pracy. Próba zdefiniowania składowych opieki medycznej, które mają wpływ na uzyskanie satysfakcji z leczenia oraz określenie zależności między zadowoleniem z leczenia a przestrzeganiem zaleceń lekarskich. Ocena zadowolenia ze stosowanego dotychczas leczenia AZS u dzieci.

Materiał i metodyka. W badaniu wzięło udział 119 dzieci w wieku od 6 miesięcy do 12 lat (średnia wieku - 4,9 roku) chorych na AZS. Lekarze przeprowadzali badanie podmiotowe, przedmiotowe oraz wypełniali kwestionariusz dotyczący przebiegu i nasilenia choroby, rodzaju stosowanej terapii oraz diagnostyki. Rodzice wypełniali 2 kwestionariusze dotyczące satysfakcji z leczenia (rodzaj zaleconej terapii, przestrzeganie zaleceń, kontakt $z$ lekarzem, uzyskane informacje, stopień wsparcia psychologicznego, udział rodziców w podejmowaniu decyzji terapeutycznych) oraz kwestionariusz oceny jakości życia.

Wyniki. Stwierdzono, że 56\% rodziców było niezadowolonych ze stosowanego leczenia, a $40 \%$ nie przestrzegało przynajmniej jednego z zaleceń terapeutycznych. Rodzice dzieci z lekkim przebiegiem choroby znamiennie częściej rezygnowali ze stosowania emolientów. Niezadowolenie $\mathrm{z}$ leczenia $\mathrm{w}$ grupie dzieci o ciężkim przebiegu AZS i niedostatecznej edukacji rodziców determinuje pogorszenie przestrzegania zaleceń lekarskich. Zidentyfikowano niezależne czynniki ryzyka niezadowolenia z leczenia, takie jak: nieudzielenie dostatecznego wsparcia psychologicznego $(\mathrm{OR}=20,00)$, nieuzyskanie dostatecznych informacji dotyczących choroby $(\mathrm{OR}=5,91)$, niedostateczne uczestniczenie w procesie leczenia $(\mathrm{OR}=5,31)$, niezadowolenie $\mathrm{z}$ kontaktu $\mathrm{z}$ lekarzem $(\mathrm{OR}=$ $4,9)$, niezadowolenie $z$ przeprowadzonej diagnostyki $(\mathrm{OR}=4,93)$ oraz ciężki przebieg choroby $(\mathrm{OR}=2,82)$.

Wnioski. Redukcja czynników ryzyka niezadowolenia z leczenia umożliwia poprawę stosowania się do zaleceń lekarskich w przewlekłej terapii AZS u dzieci.

\section{INTRODUCTION}

Atopic dermatitis (AD) is a chronic inflammatory diseases of the skin, accompanied by pruritus. It is often observed in children and adults living in industrialized countries. Forty-five percent of children develop AD within the first 6 months of life, $60 \%$ within the first year of life and $85 \%$ before the age of 5 [1]. The pathomechanism of skin changes results from an interaction between genetic and environmental factors as well as impairments of the skin barrier function and immune response [1].

In all patients with $\mathrm{AD}$, irrespective of age, the most prominent clinical symptom is generalized dryness of the skin, which is a result of increased transepidermal water loss and disturbances of lipid metabolism. The damage to the skin barrier makes irritating and allergenic substances penetrate easily. A complex cellular and humoral immune response leads to inflammation. In some patients food or inhaled allergens are significant elements in the pathomechanism of the disease. Atopic dermatitis patients require chronic care of the skin and periodic anti-inflammatory treatment, and they should avoid factors provoking exacerbations of symptoms. Despite chronic treatment, the disease is characterized by exacerbation and remission periods and lowers the quality of life of patients and their families.

Professional studies on AD, psoriasis and other chronic dermatological diseases in adults indicate 
that making a patient satisfied with treatment is a complicated process. The most important element contributing to this satisfaction is effectiveness of the administered therapy, which should be accompanied by good contact with medical personnel, active participation of the patient in taking therapeutic decisions, his/her sufficient knowledge of the disease, skin care methods and potential adverse effects of administered medication [2-13]. Studies of adult psoriasis patients confirm that there is a significant correlation between treatment satisfaction and satisfaction with life in general $[14,15]$, self-perception and perception of the world [15], and the role of emotions in the way of the patient's acting and thinking [16]. Fulfillment of patients' preferences regarding the management of psoriasis improves their satisfaction with the therapy [14, 16]. Both these factors correlate with improved adherence to medical recommendations, which is a key element in the care of chronic dermatological diseases [17]. Studies carried out on patients with psoriasis confirmed that the application of therapy, significant decrease of disease exacerbations and improved quality of life do not always contribute to improved satisfaction with treatment. Improved satisfaction is not always associated with clinical improvement. The increase of treatment satisfaction might result from improvement of the course of the disease and fulfillment of other expectations of the patient [3, 18-20].

Studies conducted on satisfaction with treatment in adult patients affected by chronic skin diseases demonstrated that their improved satisfaction leads to improved adherence and improved effectiveness of the treatment $[10,21]$. Similar results were obtained in the CONDA-SAT study conducted on children with moderate and severe AD [22].

Satisfaction with treatment is regarded as an important indicator of good quality health care. Identification of factors which make the patient feel satisfied with the applied therapy may improve medical care in the management of AD in children.

\section{OBJECTIVE}

The aim of the study was to evaluate satisfaction of children and their families with complex treatment of AD. The study attempted to identify major components of medical care which increase treatment satisfaction and to evaluate the association between treatment satisfaction and adherence to the doctor's recommendations.

\section{MATERIAL AND METHODS}

One hundred and nineteen children, aged 6 months to 12 years (mean age: 4.9 years), with AD diagnosed with the application of Hanifin and Rajka criteria, were enrolled in the study [23]. Each patient's parents gave written consent for their child to be enrolled. Detailed characteristics of all eligible patients are shown in Table 1. Doctors completed Questionnaire No. 1 evaluating the course and exacerbation of the disease, the type of recommended therapy (emollients, glucocorticosteroids, calcineurin inhibitors, antihistamines and elimination diet) and diagnostics. To estimate total consumption of skin care products, mainly for economic reasons, we distinguished emollients (trade products) and magistral preparations (ointments and creams prepared in the pharmacy). The Rajka and Langeland score was used to evaluate exacerbations of skin changes [24].

The patients' parents filled in two questionnaires: Questionnaire No. 2 regarded satisfaction with the implemented therapy: the type of recommended therapy, adherence to recommendations, contact with the doctor, obtained information on the disease and methods of skin care, degree of psychological support, and role of parents in taking decisions regarding the therapy; Questionnaire No. 3 evaluated the quality of life of children with AD. Since the Polish version of the English version of the Infants' Dermatitis Quality of Life Index [25] was unavailable, we prepared our own questionnaire. It allowed us to

Table I. Basic characteristics $(N=1 \mid 9)$

Tabela I. Charakterystyka podstawowa $(N=119)$

\begin{tabular}{lc} 
Parameter & Result \\
\hline Age, mean (SD) [years] & $4.9(3.5)$ \\
\hline Male gender & $62(52.1)$ \\
\hline Weight, mean (SD) [kg] & $20.9($ I 2.5) \\
\hline Height, mean (SD) [cm] & $109.7(25.3)$ \\
\hline Duration, median (quartile range) [years] & $3(1.5-6)$ \\
\hline Rajka score, median (quartile range) [points] & $5(4-6)$ \\
\hline Diagnostics, $n$ (\%): & $60(50.4)$ \\
\hline Skin prick tests & $66(55.5)$ \\
\hline slgE & $9(7.6)$ \\
\hline Patch skin tests & $22($ I 8.5) \\
\hline Giving up allergy diagnostics
\end{tabular}

Treatment, $n$ (\%):

\begin{tabular}{ll}
\hline Emollients & $114(95.8)$ \\
\hline Magistral drugs & $77(64.7)$ \\
\hline Topical glucocorticosteroids & $91(76.5)$ \\
\hline Calcineurin inhibitors & $62(52.1)$ \\
\hline Antihistamines & $77(64.7)$ \\
\hline Diet & $66(55.5)$ \\
\hline
\end{tabular}


make a quantitative evaluation of parameters which are key for the quality of life of children with AD and present them on a VAS scale.

The authors analyzed psychometric parameters of the questionnaire regarding the quality of life. They did not observe a ceiling-basement effect. They estimated the Cronbach's $\alpha$ coefficient, which confirmed coherence of the set of scales and thus the reliability of the quality of life questionnaire. Both the above observations allowed us to apply the questionnaire in further analyses.

\section{Statistical analysis}

Fisher's exact test and the $\chi^{2}$ test were used for categorical variables, and the Mann-Whitney test was used for continuous variables.

The associations between dependent, dichotomous variables and groups of independent variables were analyzed using logistic regression. First, logistic regression was used to assess the relationship between dependent variables and each independent variable in a univariate model. A stepwise forward procedure was then used to select variables. Predictors with $p$ levels of at least 0.1 estimated in univariate models were included in multivariate regression analyses. All statistical analyses were performed using Statistica 8.0. The null hypothesis was rejected if $p<0.05$.

\section{RESULTS}

It was confirmed that $56 \%$ of the studied patients are dissatisfied with the implemented therapy, 35\% do not consider the therapy optimal, and $42 \%$ are not satisfied with the obtained information regarding atopic dermatitis-related disorders and skin care methods. Forty-eight $(40 \%)$ parents of enrolled children admit to discontinuing at least one treatment recommendation made by the doctor in charge (Table 2). This non-adherence referred to magistral preparations and topical glucocorticosteroids, whereas antihistamines were administered in $19.3 \%$ of children although they had not been recommended (Table 2). The authors observed that the willful decision on giving up the recommended therapy depended on exacerbations of disease. Parents of children with mild AD (Rajka score $\leq 4$ points) significantly more often admitted stopping the recommended therapy (Table 2). The authors analyzed this observation in particular groups of administered drugs and noted statistical significance only for emollients (Table 2).

It was observed that in children with $\mathrm{AD}$, whose parents had been sufficiently informed (they claimed to be satisfied with the obtained information regarding atopic dermatitis-related disorders and skin care methods), the parents' lack of treatment satisfaction was not associated with worse adherence; patients with mild AD stopped adhering to medical recommendations significantly more frequently (Table 3). Patients who had not been sufficiently informed about the disease and were dissatisfied with the therapy appeared to fail to adhere to medical guidelines significantly more frequently; adherence did not depend on the degree of disease severity (Table 3). These observations confirm the results of the interactions in logistic regression analysis. In the group of patients satisfied with the obtained information on the disease, its severe course (Rajka score $>4$ ) decreased the risk of neglecting recommendations $(\mathrm{OR}=0.29 ; 95 \% \mathrm{CI}: 0.11-0.79 ; p=0.0154)$. In the group of patients not fully satisfied with the obtained information on the disease, lack of satisfaction with the therapy increased the risk of non-adherence to the doctor's guidelines, irrespective of the degree of disease severity $(\mathrm{OR}=10.0 ; 95 \% \mathrm{CI}: 1.2-86.0 ; p=0.036)$.

The authors identified independent risk factors of dissatisfaction with treatment of AD in children. Patients with moderate and severe $\mathrm{AD}(\mathrm{OR}=2.82)$ rather than patients with mild AD demonstrate a higher risk of dissatisfaction with treatment. Other factors which significantly contribute to treatment dissatisfaction refer to inadequate psychological support, i.e. receiving little support $(\mathrm{OR}=7.89)$, receiving insufficient support $(\mathrm{OR}=20.00)$ and failure to receive any support $(\mathrm{OR}=12.5)$, failure to obtain information regarding atopic dermatitis-related disorders and skin care methods $(\mathrm{OR}=5.91)$, failure to fully participate in the therapy $(\mathrm{OR}=5.31)$, dissatisfaction with the contact with the doctor $(\mathrm{OR}=4.9)$ and lack of satisfaction with diagnostic tests $(\mathrm{OR}=4.93)$ (Table 4).

An analysis of the group of children with mild $\mathrm{AD}$ (Rajka and Langeland score $\leq 4$ points) indicates that the increased risk of dissatisfaction results from not receiving sufficient information on atopic dermatitis-related disorders and skin care methods (OR = $10.33)$, cessation of diagnostics $(\mathrm{OR}=7.2)$ and unsatisfactory contact with the doctor $(\mathrm{OR}=6.67)$.

In the group of patients with moderate/severe $\mathrm{AD}$ (number of points in the Rajka and Langeland score: 4.5-9) the factors that most increase the risk of dissatisfaction with treatment include: not full engagement in the treatment $(\mathrm{OR}=24.67)$, failure to obtain sufficient psychological support $(\mathrm{OR}=18.00)$, failure to obtain sufficient information on atopic dermatitis-related disorders and skin care methods $(\mathrm{OR}=4.89)$ and unsatisfactory contact with the doctor $(\mathrm{OR}=4.10)$.

Exacerbations of symptoms of $\mathrm{AD}$ and increase of the Rajka score affected the quality of life of patients. The authors did not observe significant correlations between the quality of life and the degree 
Table 2. Associations between adherence to medical recommendations and exacerbation of symptoms according to the Rajka score Tabela 2. Analiza zależności pomiędzy przestrzeganiem zaleceń a nasileniem dolegliwości w skali Rajki

\begin{tabular}{|c|c|c|c|c|c|c|c|}
\hline \multirow[t]{2}{*}{ Variable } & \multicolumn{2}{|c|}{ Total } & \multicolumn{2}{|c|}{ Rajka score $\leq 4$} & \multicolumn{2}{|c|}{ Rajka score $>4$} & \multirow[t]{2}{*}{$P$-value } \\
\hline & $n$ & $\%$ & $n$ & $\%$ & $n$ & $\%$ & \\
\hline \multicolumn{8}{|l|}{ Emollients: } \\
\hline Aadherent to recommendations & 108 & 90.8 & 44 & 84.6 & 64 & 95.5 & 0.043 \\
\hline Non-adherent to recommendations: & II & 9.2 & - & - & - & - & \\
\hline Lack of treatment despite recommendations & 11 & 9.2 & 8 & 15.4 & 3 & 4.5 & \\
\hline Treatment despite lack of recommendations & 0 & 0 & - & - & - & - & \\
\hline \multicolumn{8}{|l|}{ Magistral preparations: } \\
\hline Adherent to recommendations & 98 & 82.4 & 42 & 80.8 & 59 & 88.1 & 0.199 \\
\hline Non-adherent to recommendations: & 21 & 17.6 & - & - & - & - & \\
\hline Lack of treatment despite recommendations & 18 & I5. I & 10 & 19.2 & 8 & 11.9 & \\
\hline Treatment despite lack of recommendations & 3 & 2.5 & - & - & - & - & \\
\hline \multicolumn{8}{|l|}{ Topical corticosteroids: } \\
\hline Adherent to recommendations & 99 & 83.2 & 43 & 82.7 & 59 & 88.1 & 0.284 \\
\hline Non-adherent to recommendations: & 20 & 16.8 & - & - & - & - & \\
\hline Lack of treatment despite recommendations & 17 & 14.3 & 9 & 17.3 & 8 & 11.9 & \\
\hline Treatment despite lack of recommendations & 3 & 2.5 & - & - & - & - & \\
\hline \multicolumn{8}{|l|}{ Calcineurin inhibitors: } \\
\hline Adherent to recommendations & 109 & 91.6 & 48 & 92.3 & 64 & 95.5 & 0.361 \\
\hline Non-adherent to recommendations: & 10 & 8.4 & - & - & - & - & \\
\hline Lack of treatment despite recommendations & 7 & 5.9 & 4 & 7.7 & 3 & 4.5 & \\
\hline Treatment despite lack of recommendations & 3 & 2.5 & - & - & - & - & \\
\hline \multicolumn{8}{|l|}{ Antihistamines: } \\
\hline Adherent to recommendations & 96 & 80.7 & 47 & 90.4 & 64 & 95.5 & 0.229 \\
\hline Non-adherent to recommendations: & 23 & 19.3 & - & - & - & - & \\
\hline Lack of treatment despite recommendations & 8 & 6.7 & 5 & 9.6 & 3 & 4.5 & \\
\hline Treatment despite lack of recommendations & 15 & 12.6 & - & - & - & - & \\
\hline \multicolumn{8}{|l|}{ Diet: } \\
\hline Adherent to recommendations & 99 & 83.2 & 45 & 86.5 & 62 & 92.5 & 0.220 \\
\hline Non-adherent to recommendations: & 20 & 16.8 & - & - & - & - & \\
\hline Lack of treatment despite recommendations & 12 & 10.1 & 7 & 13.5 & 5 & 7.5 & \\
\hline Treatment despite lack of recommendations & 8 & 6.7 & - & - & - & - & \\
\hline \multicolumn{8}{|l|}{ Total: } \\
\hline Adherent to recommendations & 71 & 60 & 26 & 50.0 & 45 & 67.2 & 0.044 \\
\hline Non-adherent to recommendations & 48 & 40 & 26 & 50.0 & 22 & 32.8 & \\
\hline
\end{tabular}

- not analyzed due to insufficient number of observations. 


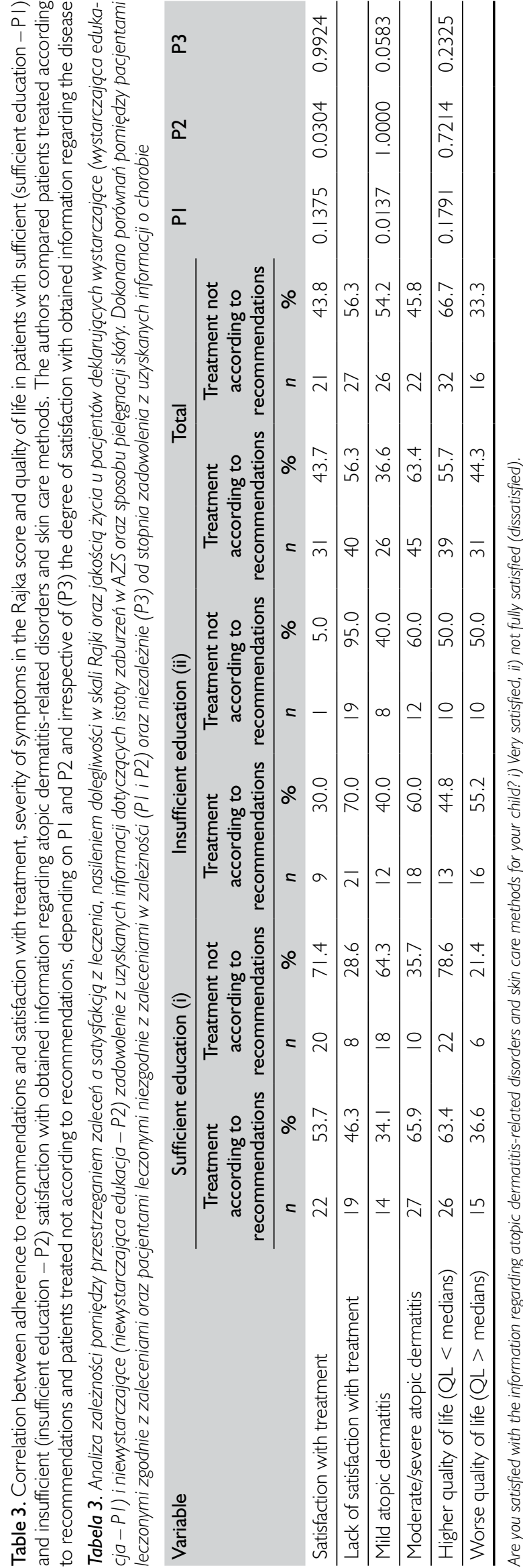

of adherence to the doctor's recommendations (data not shown).

Quantitative evaluation of the amount of applied emollients in the group of patients with mild AD who were not satisfied with the recommended therapy indicates that the amount of used emollients was significantly smaller (Fig. 1).

\section{DISCUSSION}

Satisfaction with treatment is an important indicator of good quality health care [4, 26, 27]. Improved treatment satisfaction of patients with chronic skin diseases contributes to better adherence to medical recommendations and improves the effectiveness of the therapy [10, 21]. Medical adherence is the willingness and ability of the patient to follow recommended therapy and attend medical appointments when scheduled [28]. According to Lee and Maibach, the term non-adherence, also called non-compliance, refers to a failure to follow recommendations, application of wrong doses, making wrong breaks in the administration of a drug, improper dosage of a drug, missing doses and premature termination of the therapy [29]. Non-adherence is the main reason why treatment of chronic skin diseases is unsuccessful [30-33]. Patients more often prematurely terminate topical rather than systemic therapy $[33,34]$. Low adherence/compliance worsens the course of the disease and increases the cost of health care [30].

Poor adherence is a serious problem in treating $\mathrm{AD}$ in children. American studies with the application of electronic monitoring showed that in this group of patients the mean adherence rate for treatment with topical drugs, noted in an 8-week observation period, was very low (32\%) [35]. In available databases the authors did not find studies on risk factors of treatment dissatisfaction in children with AD. Studies conducted on adult populations confirmed that independent determining factors for satisfaction with treatment of AD include professional competence of medical personnel, their sensitivity towards patients and severity of the disease [11].

An analysis of the conducted studies allowed the identification of independent factors which cause the increased risk of treatment dissatisfaction of parents/guardians of children with AD. The factors include a failure to give sufficient psychological support, failure to give sufficient information on atopic dermatitis-related disorders and skin care methods (insufficient knowledge), not full engagement in the treatment process, dissatisfaction with the contact with the doctor, lack of satisfaction with diagnostic tests, and a severe course of AD. It seems surprising, but moderate and severe course of $\mathrm{AD}$ contributes 
Table 4. Risk factors of lower satisfaction with treatment of atopic dermatitis in the single-factor logistic regression model

Tabela 4. Ocena czynników ryzyka mniejszego zadowolenia z leczenia AZS w modelu jednoczynnikowym regresji logistycznej

\begin{tabular}{|c|c|c|c|c|}
\hline \multirow{2}{*}{$\begin{array}{l}\text { Independent variables } \\
\text { Moderate/severe atopic dermatitis vs. mild atopic dermatitis }\end{array}$} & \multirow{2}{*}{$\begin{array}{l}\mathrm{OR}^{\mathrm{a}} \\
2.82\end{array}$} & \multicolumn{2}{|c|}{$95 \% \mathrm{Cl}$} & \multirow{2}{*}{$\begin{array}{l}P \text {-value } \\
0.0440\end{array}$} \\
\hline & & 1.03 & 7.72 & \\
\hline Age (continuous variable) & 0.99 & 0.86 & 1.12 & 0.8371 \\
\hline Being male & 1.37 & 0.55 & 3.39 & 0.4949 \\
\hline Disease duration & 0.91 & 0.78 & 1.06 & 0.2265 \\
\hline \multicolumn{5}{|l|}{ Diagnostics: } \\
\hline Skin prick tests & 0.88 & 0.26 & 2.92 & 0.8326 \\
\hline slgE & 0.89 & 0.26 & 3.07 & 0.8534 \\
\hline Patch skin tests & 0.52 & 0.06 & 4.45 & 0.5465 \\
\hline Giving up allergy diagnostics & 1.34 & 0.24 & 7.51 & 0.7429 \\
\hline \multicolumn{5}{|l|}{ Prescribed drugs: } \\
\hline Emollients & 1.44 & 0.28 & 7.28 & 0.6591 \\
\hline Magistral preparations & 0.92 & 0.35 & 2.43 & 0.8627 \\
\hline Topical corticosteroids & 0.73 & 0.27 & 1.96 & 0.5347 \\
\hline Calcineurin inhibitors & 0.87 & 0.33 & 2.30 & 0.7835 \\
\hline Antihistamines & 1.16 & 0.39 & 3.40 & 0.7932 \\
\hline Diet & 1.25 & 0.45 & 3.48 & 0.6662 \\
\hline \multicolumn{5}{|l|}{ Lack of treatment despite recommendations: } \\
\hline Emollients & 0.36 & 0.04 & 2.99 & 0.3416 \\
\hline Magistral preparations & 0.42 & 0.08 & 2.32 & 0.3189 \\
\hline Topical corticosteroids & 1.20 & 0.28 & 5.14 & 0.8055 \\
\hline Calcineurin inhibitors & 0.75 & 0.08 & 6.98 & 0.7997 \\
\hline Antihistamines & 0.91 & 0.08 & 10.23 & 0.9394 \\
\hline Diet & 0.27 & 0.03 & 2.26 & 0.2274 \\
\hline Question I: I was partly engaged vs. actively engaged & 5.31 & 2.03 & 13.88 & 0.0007 \\
\hline Question 2: I would like to engage partly vs. engage actively & 0.45 & 0.10 & 2.10 & 0.3092 \\
\hline Question 3: No vs. yes & 41.25 & 8.94 & 190.36 & $<0.0001$ \\
\hline Question 4: Partly satisfied/dissatisfied vs. very dissatisfied & 5.91 & 2.14 & 16.33 & 0.0006 \\
\hline Question 5: Partly satisfied/dissatisfied vs. very dissatisfied & 4.90 & 1.83 & 13.08 & 0.0015 \\
\hline Question 6: Partly satisfied/dissatisfied vs. very dissatisfied & 4.93 & 1.91 & $12.7 \mid$ & 0.0010 \\
\hline Question 7: Obtained sufficient support: & ref & & & \\
\hline Obtained little support & 7.89 & 1.46 & 42.58 & 0.0163 \\
\hline Did not obtain sufficient support & 20.00 & 3.68 & 108.58 & 0.0005 \\
\hline Did not obtain any support & 12.50 & 2.40 & 65.00 & 0.0027 \\
\hline Question 8: Need support: & ref & & & \\
\hline Do need much support & 0.31 & 0.08 & 1.22 & 0.0943 \\
\hline Do not need any support & 0.40 & 0.14 & 1.16 & 0.0920 \\
\hline
\end{tabular}

PI: Did you participate in taking the decision regarding the therapy for your child? P2: Would you like to participate in taking the decision regarding the type of treatment of atopic dermatitis administered to your child? P3: Do you find the administered treatment optimal? P4: Are you satisfied with the information regarding atopic dermatitis-related disorders and skin care methods? P5: Are you satisfied with the contact with the doctor? P6: Are you satisfied with the diagnostic tests or the doctor's decision to cease diagnostics? P7: Did you obtain proper psychological support from medical personnel with regard to the skin disease your child is affected by? P8: Do you need psychological support with regard to the skin disease your child is affected by? Ref - referential category. ${ }^{\circ}$ Dependent variable: The patient states that he/she is fully satisfied/partially satisfied vs. partially satisfied/unsatisfied. 


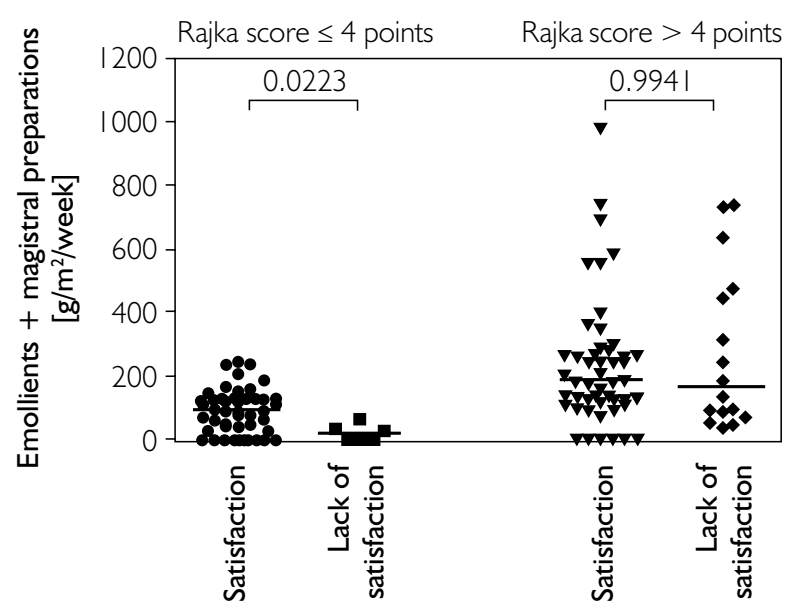

Figure I. Amount of administered emollients and magistral preparations ( $\mathrm{g} / \mathrm{m}^{2} /$ week) depending on the degree of disease severity and satisfaction with treatment

Rycina I. Zużycie emolientów oraz leków recepturowych $\left(\mathrm{g} / \mathrm{m}^{2} /\right.$ tydzień) w zależności od ciężkości przebiegu choroby oraz od stopnia zadowolenia z leczenia

to a three-fold increase in risk of dissatisfaction, and the other factors increase that risk five up to twenty times.

Causes of treatment dissatisfaction presented in the study are similar to causes of decreased adherence/compliance in $\mathrm{AD}$ and psoriasis observed in other studies on this problem. A therapeutic intervention, i.e. providing parents with more information on atopic dermatitis-related disorders and skin care methods (Therapeutic Patient Education $\mathrm{TPE})$, results in an increase in adherence, decrease of SCORAD, better quality of life [36-39] and higher satisfaction with treatment [12]. Improved doctor-parent interaction increases adherence, effectiveness of the therapy and treatment satisfaction of AD $[21,40]$. A good relationship between the doctor, the child and his/her parents increases adherence. It allows one to create therapy tailored for a particular patient and parents but also reduces the number of potential adverse effects $[41,42]$ and facilitates identification of problems related to chronic AD and solving them $[42,43]$. A meta-analysis of studies on adherence to the treatment of AD showed that a good doctor-patient relationship is the most important factor determining high adherence and satisfaction with the therapy [10]. Professional literature on active involvement of patients in making therapeutic decisions (shared decision-making - SDM), containing information on therapeutic preferences of the patient and chosen treatment method, demonstrated that the SDM pattern, repeatable during subsequent appointments, is an effective method for a long-term increase in the satisfaction with treatment in patients with a chronic disease and allows them to adhere to medical recommendations [13].
An analysis of the information given in the questionnaires indicates that $50 \%$ of parents of children affected by mild AD admit that they fail to adhere to at least one of the given therapeutic recommendations and in the group of children with moderate/ severe $\mathrm{AD}$ the percentage is $32.8 \%$. In most cases parents, without consultation with the doctor, stop using topical glucocorticosteroids and emollients. The authors observed that parents of children with mild AD more often willfully discontinued the recommended therapy; the observation was statistically significant only for emollients. The authors did not confirm that discontinuation of administration of emollients, magistral preparations, topical glucocorticosteroids, calcineurin inhibitors, recommended diet or antihistamines was a risk factor of dissatisfaction with treatment.

The analysis of the relationship between treatment satisfaction and the administration of emollients and magistral preparations, with special consideration given to the amount of the applied drug, showed that satisfied parents of children with mild AD administered proper doses of emollients more frequently (above $200 \mathrm{~g} /$ week, which means they apply the drug at least twice a day). The authors observed statistical significance between the adherence to emollient therapy and satisfaction with it only in children with mild AD. In the group of children with severe AD adherence depends on disease exacerbations. A relationship between satisfaction with the treatment and the quality of life was not observed. The professional literature contains one publication (CONDA-SAT study) on a relationship between satisfaction with treatment, adherence and quality of life in children with moderate and severe AD. The authors of the study confirmed that patients who were highly satisfied with the treatment adhered to recommended therapy more willingly and symptoms of the disease abated [22].

The assessments of the treatment satisfaction of parents/guardians of children with AD should be included in medical practice because treatment satisfaction is a significant factor which contributes to long-lasting continuation of therapy based on evidence-based medicine (EBM) and thus decreases the probability of implementing an alternative therapy [44].

\section{CONCLUSIONS}

An evaluation of satisfaction with treatment of AD in children is a simple tool which allows a doctor to draw initial conclusions regarding adherence to the recommended therapy. Higher treatment satisfaction in children with mild AD is a significant factor which contributes to long-lasting continuation of the emollient therapy. Insufficiently educated parents 
more often report lack of satisfaction with treatment; they rarely adhere to medical recommendations in severe AD. Unsatisfactory psychological support, insufficient disease education and lack of parents' active engagement in a therapy more significantly increase dissatisfaction with treatment than disease severity itself.

\section{Conflict of interest}

The authors declare no conflict of interest.

\section{References}

1. Akdis C.A., Akdis M., Bieber T., Bindslev-Jensen C., Boguniewicz M., Eigenmann P., et al.: Diagnosis and treatment of atopic dermatitis in children and adults: European Academy of Allergology and Clinical Immunology/ American Academy of Allergy, Asthma and Immunology/ PRACTALL consensus report. Allergy 2006, 61, 969-987.

2. Nijsten T., Margolis D.J., Feldman S.R., Rolstad T., Stern S.R.: Traditional systemic treatments have not fully met the needs of psoriasis patients: results from a national survey. J Am Acad Dermatol 2005, 52, 434-444.

3. Misery L., Finlay A.Y., Martin N., Boussetta S., Nguyen C., Myon E., et al.: Atopic dermatitis: impact on the quality of life of patients and their partners. Dermatology 2007, 215, 123-129.

4. Leung Y.Y., Tam L.S., Lee K.W., Leung M.H., Kun E.W., Li E.K.: Involvement, satisfaction and unmet health care needs in patients with psoriatic arthritis. Rheumatology $2009,48,53-56$.

5. Szepietowski J., Reich A., Palotai T., Kaszuba A., Chodorowska G., Brzezińska-Wcisło L., et al.: Zadowolenie pacjentów z leczenia przeciwłuszczycowego: wyniki badania PSO Survey w Polsce. Dermatol Klin 2009, 11, 129-133.

6. Umar N., Litaker D., Schaarschmidt M.L., Peitsch W.K., Schmieder A., Terris D.D.: Outcomes associated with matching patients' treatment preferences to physicians' recommendations: study methodology. BMC Health Serv Res 2012, 12, 1 .

7. Umar N., Schaarschmidt M.L., Schmieder A., Peitsch W.K., Schollgen I., Terris D.D.: Matching physicians' treatment recommendations to patients' treatment preferences is associated with improvement in treatment satisfaction. JEADV 2013, 27, 763-770.

8. Jankowiak B., Sekmistrz S., Kowalewska B., Niczyporuk W., Krajewska-Kułak E.: Zadowolenie z życia w grupie chorych na łuszczycę. Adv Dermatol Allergol 2013, 30, 85-90.

9. Finlay A.Y., Ortonne J.P.: Patient satisfaction with psoriasis therapies: an update and introduction to biologic therapy. J Cutan Med Surg 2004, 8, 310-320.

10. Serup J., Kettis L., Maroti M., Kjellgren K., Niklasson E., Ring L., et al.: To follow or not to follow dermatological treatment - a review of the literature. Acta Dermatol Venereol 2006, 86, 193-197.

11. Schmitt J., Csotonyi F., Bauer A., Meurer M.: Determinants of treatment goals and satisfaction of patients with atopic eczema. JDDG 2008, 6, 458-466.

12. Agner T.: Compliance among patients with atopic eczema. Acta Derm Venereol 2005, 215, 33-35.

13. Joosten E.A., DeFuentes-Merillas L., de Weert G.H., Sensky T., van der Staak C.P., de Jong C.A.: Systematic review of the effects of shared decision-making on patient satisfaction, treatment adherence and health status. Psychother Psychosom 2008, 77, 219-226.
14. Basińska M.A., Drozdowska M.: Emotional intelligence as an indicator of satisfaction with life of patients with psoriasis. Adv Dermatol Allergol 2013, 30, 365-372.

15. Van Cranenburgh O.D., de Korte J., Sprangers M.A., de Rie M.A., Smets E.M.: Satisfaction with treatment among patients with psoriasis: a web-based survey study. Br J Dermatol 2013, 169, 398-405.

16. Solovan C., Marcu M., Chiticariu E.: Life satisfaction and beliefs about self and the word in patients with psoriasis: brief assessment. Eur J Dermatol 2014, 24, 242-247.

17. Ersser S.J., Surridge H., Willes A.: What criteria do patients use when judging the effectiveness of psoriasis management? J Eval Clin Pract 2002, 8, 367-376.

18. Hudak P.L., Mc Keever P., Wright J.G.: The metaphor of patients as customers. Implications for measuring satisfaction. J Clin Epidemiol 2003, 56, 103-108.

19. Fisher D., Stewart A.L., Bloch D.A., Loring K., Lauternt D., Holman H.: Capturing the patient's view of change as a clinical outcome measure. JAMA 1999, 282, 1157-1162.

20. Atkinson M.J., Sinha A., Hass S.L., Colman S.S., Kumar R.N., Brod M., et al.: Validation of a general measure of treatment satisfaction, the Treatment Satisfaction Questionnaire for Medication (TSQM), using a national panel study of chronic disease. Health Qual Life Outcomes 2004, 2, 12.

21. O'Neill J.L., Feldman S.R.: Practical ways to improve patients use of their medications. Dermatology 2009, 14, 85-92.

22. Torreloa A., Ortizb J., Alomarc A., Rosc S., Pedrosad E., Cuervo J.: Health-related quality of life, patient satisfaction, and adherence to treatment in patients with moderate or severe atopic dermatitis on maintenance therapy: the CONDA-SAT Study. Actas Dermosifiliogr 2013, 104, 409-417.

23. Hanifin J.M., Rajka G.: Diagnostic features of atopic eczema. Acta Dermatol Venereol (Stockh) 1980, 92, 352-358.

24. Rajka G., Langeland T.: Grading of the severity of atopic dermatitis. Acta Derm Venereol (Stockh) 1989, suppl. 144, 13-14.

25. Lewis-Jones M.S., Finlay A.Y., Dykes P.J.: The infant's dermatitis quality of life index. Br J Dermatol 2001, 144, 104-110.

26. Rosenthal G.E., Shannon S.E.: The use of patient perceptions in the evaluation of health-care delivery system. Med Care 1997, 35, 58-68.

27. Cleay P.D., McNell B.J.: Patient satisfaction as an indicator of quality care. Inquiry 1988, 25, 25-36.

28. Murphy J., Coster G.: Issues in patient compliance. Drugs $1997,54,797-800$

29. Lee I.A., Maibach H.I.: Pharmionics in dermatology: a review of topical medications. Am J Clin Dermatol 2006, 7, 231-236.

30. Olsterberg L., Blaschke T.: Adherence to medications. N Engl J Med 2005, 353, 487-497.

31. Brown K.L., Krejci-Manwaring J., Tusa M.G., Camacho F., Fleischner A.B.: Poor compliance with topical corticosteroids for atopic dermatitis despite severe disease. Dermatol Online J 2008, 14, 13.

32. Ali S.M., Brodell R.T., Balkrishnan R., Feldman S.R.: Poor adherence to treatments: a fundamental principle of dermatology. Arch Dermatol 2007, 43, 912-915.

33. Balkrishnan R.: The importance of medical adherence in improving chronic-disease related outcomes: what we know and what we need to further know. Med Care 2005, $43,517-520$

34. Krejci-Manwaring J., Mc Carty M.A., Camacho F., CarollC., Johnson K., Manuel J., et al.: Adherence to topical treatment is poor as compared with adherence with oral agents: implications for effective clinical use of topical agents. J Am Acad Dermatol 2006, 54, 5235-5236. 
35. Krejci-Manwaring J., Tusa M.G., Caroll C., Camacho F. Kaur M., et al.: Stealth monitoring of adherence to topical medication: adherence is very poor in children with atopic dermatitis. J Am Acad Dermatol 2007, 56, 211-216.

36. Barbarot S., Bernier C., Deleuran M., De Raeve L., Eichenfield L.: Therapeutic patient education in children with atopic dermatitis: position paper on objectives and recommendations. Pediatr Dermatol 2013, 30, 199-2016.

37. Stalder J.F., Bernier C., Ball A., De Raeve L., Gieler U., Deleuran M., et al.: Therapeutic patient education in atopic dermatitis: worldwide experiences. Pediatr Dermatol 2013 30, 329-334.

38. Grillo M., Gassner L., Marshman G., Dunn S., Hudson P.: Pediatric atopic eczema: the impact of an educational intervention. Pediatr Dermatol 2006, 23, 428-436.

39. Mason J.M., Carr J., Buckley C., Hewitt S., Berry P., Taylor J., et al.: Improved emollient use reduces eczema symptoms and is cost neutral in infants: before-and-after evaluation of a multifaceted educational support programme. BMC Dermatol 2013, 13, 7.

Received: 6X 2015

Accepted: 7 III 2016
40. Yukihiro O., Hywel W., Andrew S., Hirohisa S., Yoji I., et al.: Psychosocial factors and adherence to treatment advice in childhood atopic dermatitis. J Invest Dermatol 2001, $117,852-857$.

41. O'Toole A., Thomas B., Thomas T.: The care triangle: determining the gaps in the management of atopic dermatitis. J Cutan Med Surg 2013, 17, 276-282.

42. Ou H.T., Feldman S.R., Balkrishnan R.: Understanding and improving treatment adherence in pediatric patients. Semin Cutan Med Surg 2010, 29, 137-140.

43. Santer M., Burgess H., Yardley L., Ersser S.J., Lewis-Jones S., Muller J., et al.: Managing childhood eczema: qualitative study exploring carers' experiences of barriers and facilitators to treatment adherence. J Adv Nurs 2013, 69, 24932501.

44. Jensen P.: Alternative therapy for atopic dermatitis and psoriasis: patient-reported motivation, information source and effect. Acta Derm Venereol 1990, 70, 425-428. 